\title{
Study of ultrafiltration of defatted whey protein concentrates (WPC) withdrawn from an industrial plant
}

\author{
G Daufin 1, F Michel 1, U Merin 2 \\ 1 INRA, Laboratoire de Recherches de Technologie Laitière, \\ 65, rue de Saint-Brieuc, 35042 Rennes Cedex, France; \\ 2 Dairy Science Laboratory Agricultural Research Organization, \\ The Volcani Center, PO Box 6, Bet Dagan 50280 Israel
}

(Received 3 January 1991; accepted 20 December 1991)

\begin{abstract}
Summary - This study deals with the ultrafiltration (UF) of defatted clarified whey protein concentrates (WPC) using inorganic M5 Carbosep membranes. Based on a prior knowledge of operating conditions and performance of an industrial 4-stage UF plant $\left(150 \mathrm{~m}^{2}\right)$, an experimental laboratory study was carried out using a monotube rig $\left(2.26 \times 10^{-2} \mathrm{~m}^{2}\right)$ and feed withdrawn from the industrial plant. Flux $(J)$ versus transmembrane pressure $(T P)$ has shown that membrane permeability is significantly improved after defatting clarification (thermocalcic treatment followed by microfiltration). Moreover, no marked limiting fluxes were noted, particularly over a sufficient tangential flow-rate $\left(4.5\right.$ or $5.5 \mathrm{~m}^{-1} \mathrm{~s}^{-1}$ ), so that the membrane could operate at higher fluxes. UF at fluxes equal to those performed by the equipment have confirmed the forecast. Four fouling regimes have been found, which depend on flux, protein concentration, tangential flow rate and the nature of the fouling components (protein adsorption; insoluble salt precipitates on and in the membrane). Reversible phenomena are the major contributors to pressure increase at constant flux but irreversible fouling, Rif, and its alteration rate determine either the stability of UF operating conditions or their divergence which result in an increasingly rapid TP.
\end{abstract}

ultrafiltration $/$ defatted whey protein concentrate $/$ fouling $/$ tangential flow rate $/$ inorganic membrane

Constants and variables: a, b, c: constants; $A c$ : critical value of $A=\mu r . J / \tau w, C m$ : protein concentration at membrane wall $\left(\mathrm{g} . \mathrm{I}^{-1}\right)$; $\mathrm{C}$ : concentration $\mathrm{Cp}, \mathrm{Cr}$ : protein concentration in permeate, retentate $\left(\mathrm{g} . \mathrm{l}^{-1}\right) ; D$ : diffusion coefficient $\left(\mathrm{m}^{2} . \mathrm{s}^{-1}\right) ; d h$ : hydraulic diameter of membrane $(\mathrm{m}) ; F$ : correcting factor of mass transfer coefficient; $J$ : ultrafiltration flux $\left(I . h^{-1} \cdot \mathrm{m}^{-2}\right) ; J$ lim: limiting flux $\left(I . \mathrm{h}^{-1} \cdot \mathrm{m}^{-2}\right) ; J w, J w$. pure water flux before, after UF $\left(\mathrm{l} . \mathrm{h}^{-1} \cdot \mathrm{m}^{-2}\right) ; \mathrm{Jpl}$ : plant flux $\left(\mathrm{l} . \mathrm{h}^{-1} \cdot \mathrm{m}^{-2}\right) ; k$. mass transfer coefficient $\left(\mathrm{l} \cdot \mathrm{h}^{-1} \cdot \mathrm{m}^{-}\right.$ $\left.{ }^{2}\right)$; $L$ : UF tube length (m); $P D$ : pressure drop along UF tube (bar); Re: Reynolds number; $R f$ t total fouling hydraulic resistance $\left(\mathrm{m}^{-1}\right)$; Rif. irreversible fouling hydraulic resistance $\left(\mathrm{m}^{-1}\right) ; R m$ : membrane hydraulic resistance $\left(\mathrm{m}^{-1}\right)$; Rrt. reversible fouling hydraulic resistance $\left(\mathrm{m}^{-1}\right)$; $S c$ : Schmidt number; Sh: Sherwood number; TR: apparent retention rate; TP: transmembrane pressure (bar); TPi: initial transmembrane pressure (bar); TPf: final transmembrane pressure (bar); $\tau W$. tangential shear stress $(\mathrm{Pa}) ; v$. tangential flow-rate $\left(\mathrm{m} . \mathrm{s}^{-1}\right) ; \mu r, \mu p, \mu \mathrm{w}$. dynamic viscosity of retentate, permeate, water (Pa.s); $\rho$ : specific mass $\left(\mathrm{kg} \cdot \mathrm{m}^{-3}\right)$. 
Résumé - Ultrafiltration de concentrés de protéines de lactosérum délipidé produits industriellement. Ce travail est consacré à l'étude de l'ultrafiltration de concentrés de protéines de lactosérum délipidé sur une membrane inorganique Carbosep (M5). II repose sur l'analyse des performances d'une installation industrielle et la simulation du fonctionnement de chacun de ses 4 étages à l'aide d'une boucle de laboratoire. Les caractéristiques flux, J (pression transmembranaire, PT) révèlent l'absence de flux limite significatif, en particulier, aux vitesses d'écoulement tangentiel choisies industriellement ( 4,5 et $5,5 \mathrm{~m} \cdot \mathrm{s}^{-1}$ selon la concentration en protéines). Quatre allures de colmatage régissent le fonctionnement de la membrane en fonction du temps et permettent de faire des prévisions sur les durées de fonctionnement et les flux qui pourraient être visés. Les phénomènes de colmatage réversibles sont dominants mais l'évolution du système d'ultrafiltration au cours du temps est gouvernée par l'augmentation de l'encrassement irréversible (adsorption de protéines, précipités de sels insolubles).

ultrafiltration / concentré de protéines de lactosérum délipidé / colmatage / membrane inorganique / vitesse de filtration tangentielle

\section{INTRODUCTION}

Since the emergence of the ultrafiltration technique during the early 1970 s and its subsequent improvements, a large variety of whey protein concentrates (WPC) with proteins/total solids ratios in the range of $35-85 \%$ has been produced by the dairy industry. These WPC are used in baby food formulations, fermented sausages and protein-enriched beverages due to their functional properties and their nutritional value (Marshall and Harper, 1988). The production of WPC has grown continuously during the last decade in direct relation to the increase in UF membrane area (van der Horst and Hanemaaijer, 1989).

Nevertheless, the performance of industrial equipment for whey UF is limited due to the presence of whey constituents such as proteins and insoluble calcium salts, which are responsible for membrane fouling (Labbé et al, 1990).

The presence of phospholipids (PL) in WPC limits their versatile use in some products which utilize their foaming ability and other functional properties, and in the production of protein hydrolysates (Maubois, 1987).

Numerous pretreatments for the removal of PL before UF have been proposed over the last 15 years (Muller and Harper, 1979; Merin et al, 1983; Patocka and Jelen, 1987). Thermocalcic aggregation of phospholipids and subsequent separation of the precipitate by crossflow microfiltration (CFMF) has been proposed by Fauquant et al (1985) and Maubois et al (1987), for whey clarification treatment. By ultrafiltrating clarified whey, it was possible to obtain WPC with $95 \%$ protein purity (Maubois, 1988). Our first studies (Taddéi et al, 1986; Maubois et al, 1987) using M4 (SFEC) and Iris (Rhône Poulenc) membranes showed that protein retention was reduced $(60 \%)$ if the same membrane cutoff were used for ultrafiltering crude and defatted wheys.

In this work, at the laboratory we simulated a multi-stage industrial installation (composed of over $140 \mathrm{~m}^{2}$ Carbosep M5 UF membranes) with the purpose of quantifying the phenomena which govern mass transfer through the membrane and its evolution with time in UF of clarified whey. 


\section{MATERIALS AND METHODS}

\section{MF-UF industrial installation}

To prepare high purity WPC > 85-95\% protein in dry matter, Eurial Co (Nantes, France) adopted the INRA thermocalcic aggregation and clarification process (Fauquant et al, 1985) and purchased $57 \mathrm{~m}^{2}$ of M14 Carbosep UF membranes (0.2- $\mu \mathrm{m}$ pore size) and a $143.6 \mathrm{~m}^{2}$ 4-stage UF plant equipped with M5 Carbosep UF membranes (10 kDa, Tech Sep, Miribel, France). To whey at $2{ }^{\circ} \mathrm{C}, 2.2 \mathrm{~g} . \mathrm{l}^{-1} \mathrm{Ca}$ was added by a dosing pump and $\mathrm{pH}$ was adjusted to 7.2 by $\mathrm{NaOH}$. The whey was heated to $55^{\circ} \mathrm{C}$ for $8 \mathrm{~min}$, using a plate heat exchanger and microfiltered at constant average flux of $67 \mathrm{I} \cdot \mathrm{h}^{-1} \cdot \mathrm{m}^{-2}$ with a transmembrane pressure (TP) which increased from 0.8 up to 2.9 bar. After 5-12 h of operation it resulted in shut-down due to limiting flux or pressure, and cleaning of the installation was required. UF temperature was $54^{\circ} \mathrm{C}$ or less, which reduced severe and rapid fouling. This result and the observed relation between the slow fouling of the heat exchanger when $\mathrm{Ca}^{2+}$ and $\mathrm{OH}^{-}$were added during the thermocalcic destabilization and the improved performance of the UF indicated that inorganic components were one of the most important factors in the system.

\section{Laboratory facilities}

Three major differences existed between laboratory and factory units:

- for laboratory experiments the microfiltrate was kept at $3-4{ }^{\circ} \mathrm{C}$ for some hours before reheating to $50^{\circ} \mathrm{C}$;

- time required to achieve stationary protein concentration (10 $\mathrm{min}$ in the first stage; 2 to 2.5 hours at the other UF stages in the industrial plant compared to a short period of time in the laboratory);

- average TP was measured for 2 UF modules (252 tubes/module) in series in the factory, compared to a single tube in the laboratory, which could cause differences in permeation owing to different reversible or irreversible fouling (Tarnawski and Jelen, 1986).

\section{Laboratory operating procedure}

The following feed streams were used: rennet casein whey (W), microfiltrate of destabilized whey (MF), UF retentates (withdrawn from stages $1-4, \mathrm{C} 1-\mathrm{C} 4$, diafiltered accordingly; table I) of clarified rennet casein whey, obtained from the factory.

Table I. Chemical composition of feed streams $\left(\mathrm{g} \cdot \mathrm{l}^{-1}\right)$. Composition chimique des produits utilisés $\left(g . f^{-1}\right)$.

\begin{tabular}{|c|c|c|c|c|}
\hline $\begin{array}{l}\text { Products } \\
\left(\mathrm{pH} \text { at } 50^{\circ} \mathrm{C}\right)\end{array}$ & $\begin{array}{l}\text { Total } \\
\text { dry } \\
\text { matter }\end{array}$ & $\begin{array}{l}\text { Total nitrogen } \\
(N \times 6.38)\end{array}$ & $\beta$-Lactoglobulin & $\alpha$-Lactalbumin \\
\hline
\end{tabular}

\begin{tabular}{lrrrrr} 
Whey (6.4) & 70 & 10.9 & 3.6 & 1.2 & 0.4 \\
Microfiltrate (6.5) & 65 & 8.4 & 3.5 & 1.1 & 0.5 \\
C1 (6.5) & 75 & 20.0 & 12.0 & 3.6 & 0.8 \\
C2 diafil (6.6) & 112 & 100.0 & 70.0 & 18.0 & 0.6 \\
C3 diafil (6.7) & 130 & 109.0 & 63.0 & 20.0 & 0.8 \\
C4 (6.6) & 220 & 195.0 & 130.0 & 35.0 & 1.7 \\
\hline
\end{tabular}

Diafil: diafiltered.

Diafil: diafiltré. 
Ultrafiltration of these feed streams led to the study of characteristics of J(TP), at different tangential flow velocities, $v$, and $T P(t)$ at constant fluxes, $J$, as described by Taddéi (1986) and Taddéi et al (1989). The experiments were carried out at $50^{\circ} \mathrm{C}$ with total recycling of retentate and permeate. In long-term runs (up to $10 \mathrm{~h}$ ), the feed was renewed every hour in order to reduce possible whey fraction alteration, due to too long a residence time in the experimental UF loop.

A cleaning cycle was performed before and after each run according to Daufin et al (1991a). This procedure permitted tabulation of pure water flux, Jw, and fouled membrane water flux, $J$ 'w, for further calculation.

\section{Analysis of UF products}

All fluids were checked for $\mathrm{pH}$, total protein $(N \times 6.38)$ and total solids using an infrared instrument (DairyLab). $\alpha$-Lactalbumin and $\beta$-lactoglobulin were analyzed by HPLC (Fauquant et al, 1985). Total Ca was analyzed by atomic absorption (Brulé et al, 1974). The compositions of the different feed streams are given in table $\mathrm{I}$.

\section{Mass transfer characterization}

Permeation flux was measured with $\pm 0.1 \%$ precision for fluxes $>15 \mathrm{I} \cdot \mathrm{h}^{-1} \cdot \mathrm{m}^{-2}$ and better than $5-10 \%$ for flower fluxes of $1-2 \mathrm{I} \cdot \mathrm{h}^{-1} \cdot \mathrm{m}^{-2}$.

\section{Percentage protein retention}

Solute transfer through the membrane was characterized by apparent retention rate, TR, calculated as follows:

$$
T R=1-\frac{C p i}{C r i} \times 100
$$

where Cpi and Cri are the concentrations of the th constituent in the permeate and in the retentate respectively.

In accordance with the analytical procedure, the uncertainty of the soluble protein retention was $5 \%$.

\section{Data analysis}

Three complementary models of mass transfer enabled a description limiting phenomena which ruled membrane-fluid system evolution. They were aimed at providing quantitative and qualitative information on membrane fouling, and included the following: the contribution of reversible and irreversible phenomena and whether convection diffusion balance ruled mass transfer within reversible polarization layer; and what, the mass transfer coefficient value was, and reversible fouling sensitive to erosion.

\section{Mass-transfer coefficient, $\boldsymbol{k}$}

For a not totally selective membrane (protein rejection rate $<100 \%$ ) the film model (Michaels, 1968) permits a relationship to be defined between limiting flux (Jlim) and concentration of rejected solutes in the retentate, $\mathrm{Cr}$, the permeate, $\mathrm{Cp}$, and at the membrane wall, $\mathrm{Cm}$ :

$$
J \lim =k \ln \frac{C m-C p}{C r-C p}
$$

This model describes the system when the final UF flux is no longer controlled by the transmembrane pressure, but by the rate at which retained solutes are transferred by back diffusion from the membrane surface to the bulk.

The graphic presentation of $\mathrm{Jlim}=f(\mathrm{Cr}-\mathrm{Cp})$ enabled the calculation of the concentration at the membrane, $\mathrm{Cm}$, and the mass transfer coefficient, $k$.

The latter could be calculated and used in dimensionless numbers relationship of the type: $S h=a R e^{b} \cdot S c^{c}$ (Gekas and Hallstrom, 1987) such as the most used expression of ChiltonColburn:

$$
S h=0.023 R e^{0.8} S c^{1 / 3}
$$

It was corrected by René and Lalande (1989) in order to account for forces which are the outcome of radial transmembrane flux through the membrane and tangential flow in connection with the pressure drop along the UF tube:

$$
S h=2.5 \times 10^{-7} R^{1.4} S^{2 / 3} \mathrm{~F}^{1 / 2}
$$


where: $F=\frac{T P \cdot \mu r}{P D \cdot \mu p}$

In order to perform the calculations, we have considered the studied retentate protein fraction, which consisted of $75 \% \beta$-lactoglobulin and $25 \%$ $\alpha$-lactalbumin and have used the average value of the diffusion coefficient of proteins $D=7.8 \times$ $10^{-11} \mathrm{~m}^{2} \cdot \mathrm{s}^{-1}$ at $50{ }^{\circ} \mathrm{C}$ (Delaney and Donnelly, 1977).

\section{Fouling quantification and modelling: hydraulic resistance}

The "hydraulic resistance-in-series" concept enabled a description to be made of the membrane/flux system, whatever the flux, the transmembrane pressure and the time.

The measured variables $(J, J w, J$, $w, T P)$ were used for calculating the various hydraulic resistances which oppose transfer of solvent and solute, ie $R m$ : clean membrane; $R f$. total fouled membrane; sum of the reversible fouling, Rif and irreversible fouling, Rif (van den Berg and Smolders, 1988; Taddéi et al, 1989). These variables permitted calculation of the contribution of reversible fouling at the end of the UF at constant flux. The evolution of the hydraulic resistance with time was modelled according to adsorption and deposition laws for flux (Taddéi et al, 1989).

\section{Convection-erosion model}

This model describes a fouling system which is ruled by erosion of reversible fouling layers, which tend to accumulate on UF membranes.

Barnier (1990), relying on turbulent diffusion concept and laminar sub-layer, showed that a thin cake layer was formed on the UF membrane if the local concentration on the wall passed the limit, characteristic of a membranesolute combination. Under these conditions, the transformation of the characteristic of $J(T P)$ in $A$ (In Rf) where $A=\mu r J / \tau w$, and

$$
\tau w=d h . \frac{P D}{4 L}
$$

it reveals a curve divided into 2 linear parts. Its break-point permits the determination of a critical value, $A c$, which corresponds to a critical flux value, $J c$, over which further superficial accumulation of cake on the membrane takes place.

\section{RESULTS}

\section{Characteristics of $J=f(T P)$}

The $J=f(T P)$ characteristics for UF of different materials through the M5 membrane reveal that:

- the permeation fluxes of the microfiltrate were superior to those of whey (fig 1);

- permeation fluxes are most influenced by high tangential flow velocity at high pressure and/or concentration (fig 2);

- permeation decreases when protein concentration increases from 20 (C1) to 195

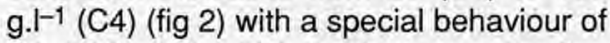
C2 (100 g. $\left.\mathrm{I}^{-1}\right)$ which leads to superior flux compared to $\mathrm{C} 1$;

- over the entire range of pressures studied ( $0-9$ bar) no limiting flux was noted except at higher pressures and lower tangential flow rate.

\section{Characteristics of TP(t) at constant flux}

The M5 membrane proved to be selective towards whey protein retention: $100 \%$ for $\beta$-lactoglobulin, and over $95 \%$ for $\alpha$ lactalbumin. A thorough study of the data collected at the industrial equipment for several months helped to create an average operating scheme for each of the stages with respect to flux and transmembrane pressure (table II).

The average flux of the installation was low: $25 \mathrm{I} \cdot \mathrm{h}^{-1} \cdot \mathrm{m}^{-2}$; the second stage showed more $\left(37.3 \mathrm{I} . \mathrm{h}^{-1} \cdot \mathrm{m}^{-2}\right)$ than the first 


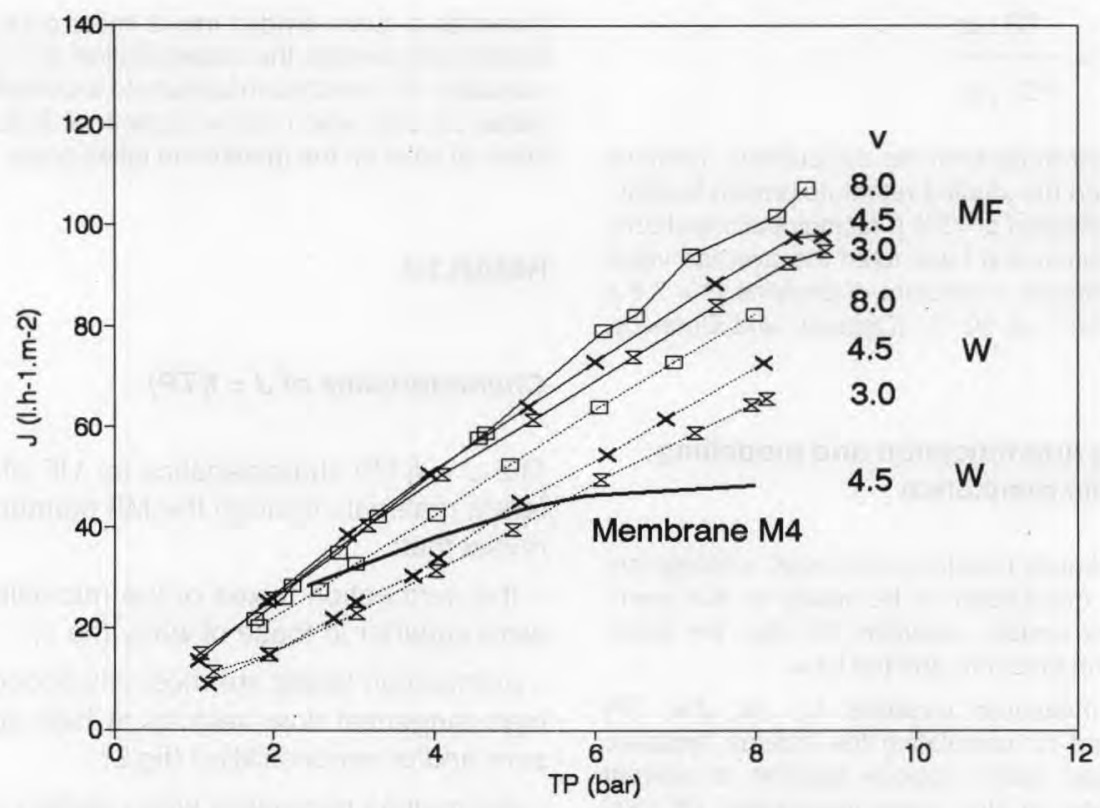

Fig 1. Influence of clarification: flux $(J)$ versus transmembrane pressure $(T P)$ at various tangential flow-rate $\left(v, \mathrm{~m}^{-1} \mathrm{~s}^{-1}\right) \cdot\left(\mathrm{M} 5,50^{\circ} \mathrm{C}\right)$. W: whey; MF: microfiltrate.

Influence de la clarification : flux $(\mathrm{J})$ en fonction de la pression de transfert (TP) à diverses vitesses d'écoulement tangentiel $\left(\mathrm{v}, \mathrm{m} \cdot \mathrm{s}^{-1}\right) .\left(\mathrm{M} 5,50^{\circ} \mathrm{C}\right)$. W : lactosérum; $\mathrm{MF}$ : microfiltrat.

(33.3 I. $\left.\mathrm{h}^{-1} \cdot \mathrm{m}^{-2}\right)$, despite the 5-6-fold increase in protein concentration.

After 8-12 h of operation (which was terminated due to insufficient material preparation by the MF unit), the final pressure was the same for the 3 stages 1, 2 and 4: 3.5 bar. Stage 3 was somewhat more fouled ( $T P f=5.2$ bar).

The laboratory UF of each of the concentrates revealed that:

- simulating UF at the laboratory using the average plant flux, Jpl, resulted in acceptable evolution of TP over time. The most altered permeability was that of the $\mathrm{C} 3$ flux (fig 3);
- when UF was simulated at fluxes higher than those practised by the factory, fouling was rapid and severe with final TP up to over 7 bar, except for the retentate $\mathrm{C} 4$ at 12.7 I. $\mathrm{h}^{-1} \cdot \mathrm{m}^{-2}$ (fig 4);

- four representative fouling behaviour curves were observed using the M5 membrane, each one representing a different phenomenon (fig 5). Depending on feed and operating conditions (flux, $\mathrm{pH}$, etc) used in the laboratory, it corresponded to slow TP increase (behaviour 4) or faster $T P$ increase up to nearly a plateau (behaviour 3), or to higher TP values with either decreasing (behaviour 2) or increasing (behaviour 1) fouling rates. 

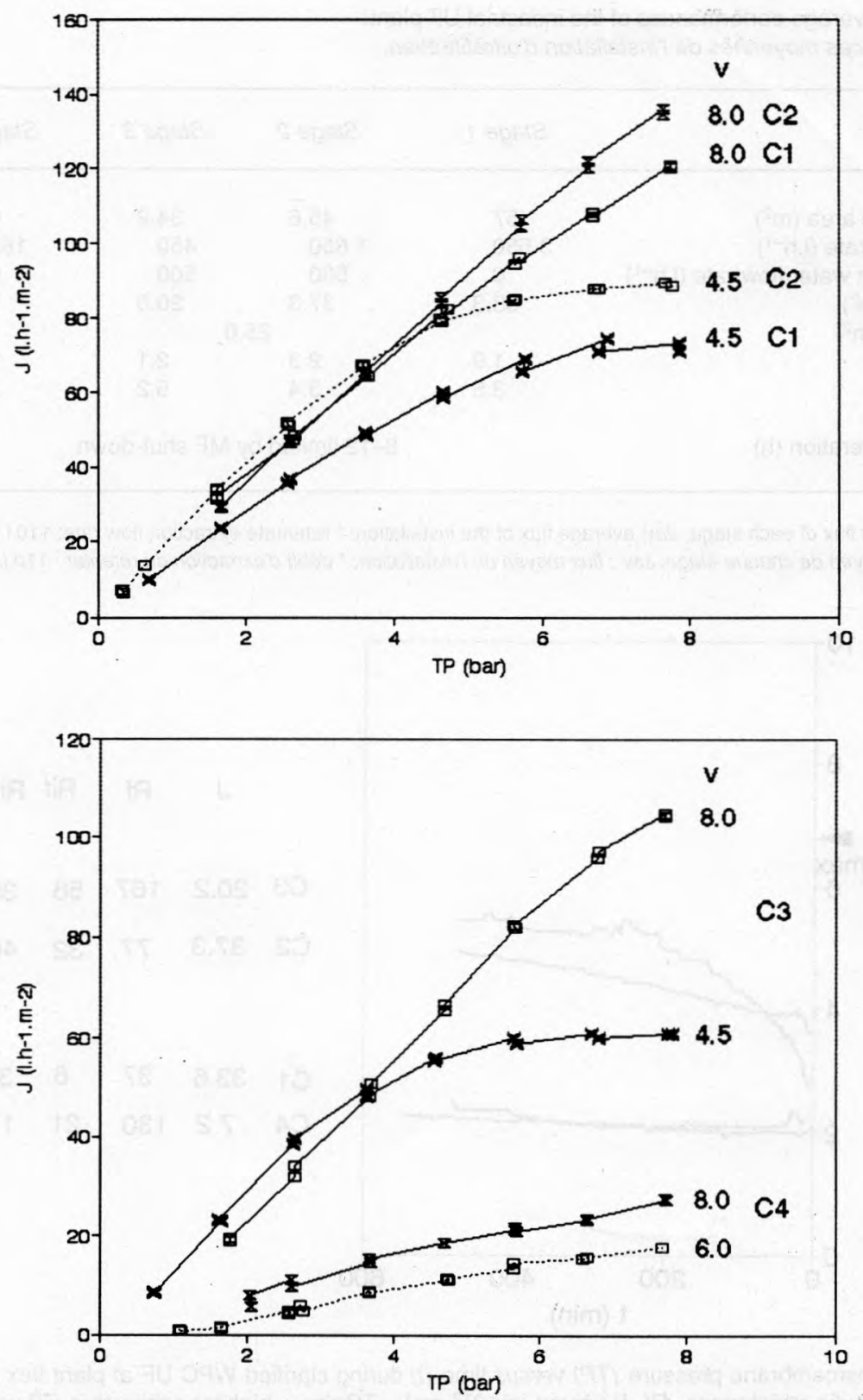

Fig 2. $J(T P)$ characteristic of clarified WPC from stages 1 to 4 (C1 to $C 4)$ at various tangentiel flowrate $\left(v, \mathrm{~m} \cdot \mathrm{s}^{-1}\right)$.

Caractéristiques J(TP) des concentrés de protéines de lactosérum clarifié des étages 1 à 4 (C1 à C4) à diverses vitesses d'écoulement tangentiel $\left(\mathrm{v}, \mathrm{m}^{\mathrm{s}} \mathrm{s}^{-1}\right)$. 
Table II. Average performances of the industrial UF plant. Performances moyennes de l'installation d'ultrafiltration.

\begin{tabular}{|c|c|c|c|c|}
\hline 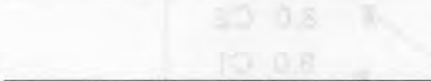 & Stage 1 & Stage 2 & Stage 3 & Stage 4 \\
\hline Membrane area $\left(\mathrm{m}^{2}\right)$ & 57 & 45.6 & 34.2 & 6.8 \\
\hline Feed flow rate $\left(\mathrm{I} . \mathrm{h}^{-1}\right)$ & 3550 & 1650 & 450 & $160^{*}$ \\
\hline Diafiltration water flow rate $\left(1 . \mathrm{h}^{-1}\right)$ & 0 & 500 & 500 & 0 \\
\hline$J p /\left(I . h^{-1} \cdot m^{2}\right)$ & 33.3 & 37.3 & 20.0 & 7.3 \\
\hline $\operatorname{Jav}\left(I . \mathrm{h}^{-1} \cdot \mathrm{m}^{2}\right)$ & \multicolumn{4}{|c|}{25.0} \\
\hline TPi (bar) & 1.9 & 2.3 & 2.1 & 1.2 \\
\hline TPf (bar) & 3.5 & 3.4 & 5.2 & 3.5 \\
\hline Time of operation (h) & \multicolumn{4}{|c|}{$8-12$ limited by MF shut-down } \\
\hline
\end{tabular}

$\mathrm{Jpl}$ : average flux of each stage; Jav. average flux of the installation; * retentate extraction flow rate: $110 \mathrm{I} . \mathrm{h}^{-1}$. $\mathrm{Jpl}$ : flux moyen de chaque étage; Jav : flux moyen de l'installation; " débit d'extraction du rétentat : $110 \mathrm{l} . \mathrm{h}^{-1}$.

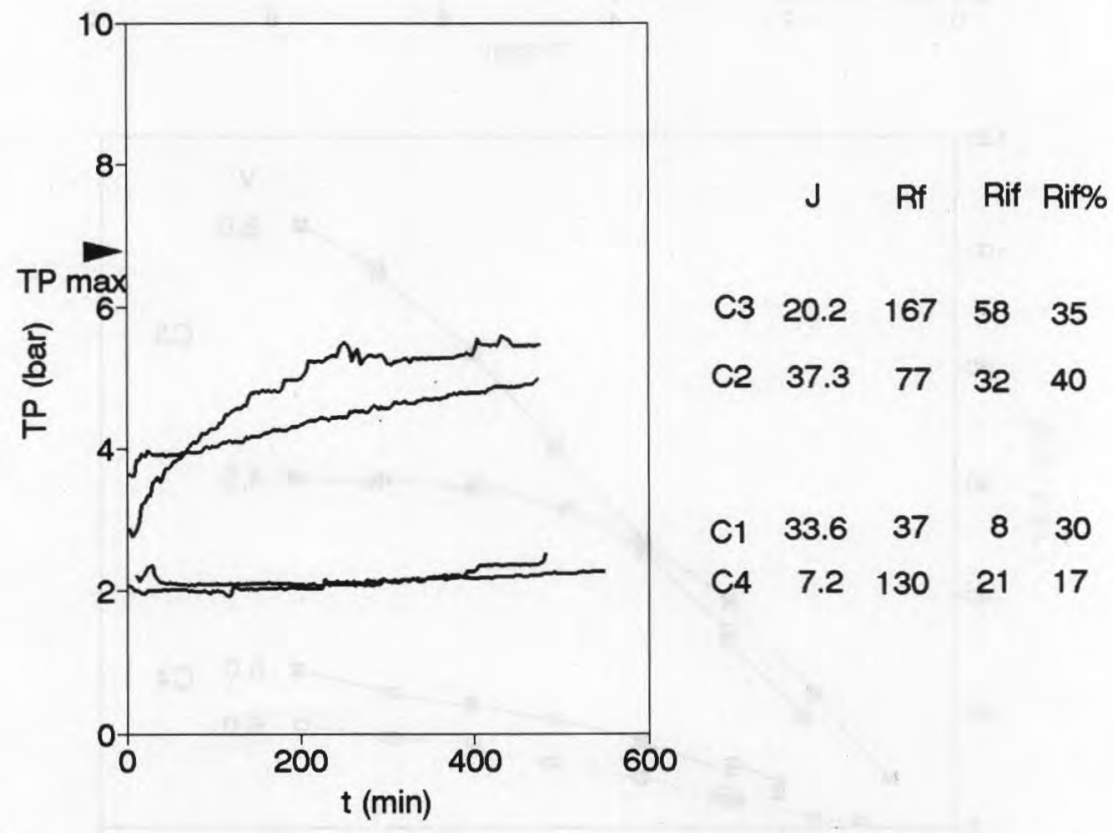

Fig 3. Transmembrane pressure (TP) versus time (t) during clarified WPC UF at plant flux (Jpl, I. $\mathrm{h}^{-1}$. $\mathrm{m}^{-2}$ ) (hydraulic resistances, Rf, Rif given in $10^{12} \mathrm{~m}^{-1}$ ). TPmax $=$ highest achievable TP value in the plant.

Évolution de la pression de transfert (TP) au cours du temps (t) lors de l'ultrafiltration des concentrés de protéines de lactosérum clarifié à flux usine (Jpl, I. $\mathrm{h}^{-1} \cdot \mathrm{m}^{-2}$ ) (les résistances hydrauliques Rf, Rif sont données en $10^{12} \mathrm{~m}^{-1}$ ). TP max = valeur maximale de TP sur l'installation industrielle. 


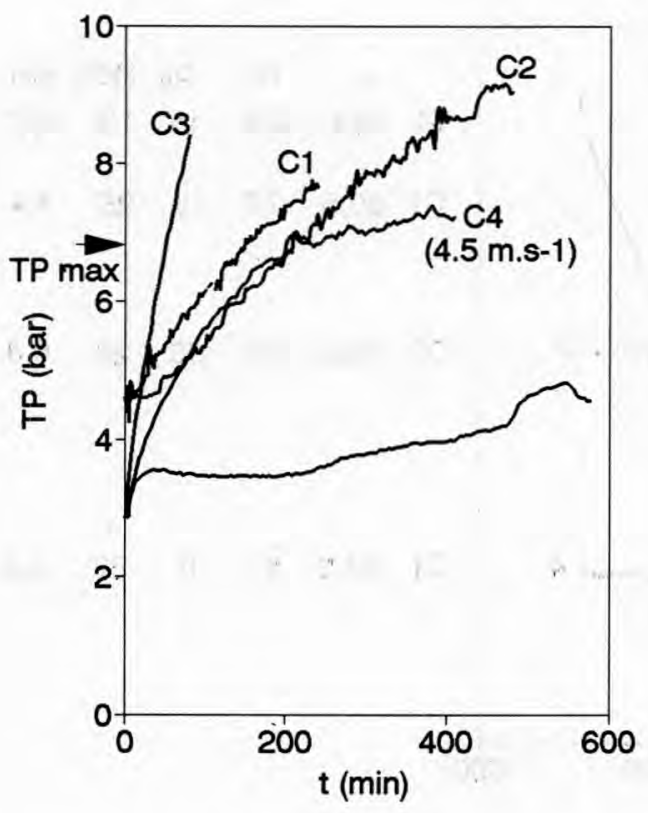

C4 $12.7 \quad 230 \quad 26 \quad 12$

Fig 4. Transmembrane pressure (TP) versus time (t) during clarified WPC at flux higher than Jpl (Rf, Rif in $10^{12} \mathrm{~m}^{-1}$ ).

Évolution de la pression de transfert (TP) au cours du temps (t) lors de l'ultrafiltration des concentrés de protéines de lactosérum clarifié à flux supérieurs aux flux usine (Rf, Rif en $10^{12} \mathrm{~m}^{-1}$ ).

\section{DISCUSSION}

\section{Significance of J(TP) characteristics}

According to Taddéi (1986) and Taddéi et al (1986) knowledge of J(TP) characteristics of an UF membrane is quite informative, provided that alteration of membrane hydraulic resistance with time (also reported by Tarnawski and Jelen (1986)) is taken into account.

In most cases, limiting fluxes did not exist with the defatted whey retentates, contrarily to what Taddéi (1986) systematically observed when ultrafiltering crude sweet whey and sweet whey UF retentates (up to 56 g..$^{-1}$ nitrogen matter) with a Carbosep M4 membrane (20 kDa cutoff) (fig 1). These results clearly show that whey clarification allows improvement of flux performances of M5 membrane, which is in agreement with the results reported for an M4 membrane (Piot et al, 1984).

However, as the hydraulic resistance of the M5 membrane, $R m$, is higher (nearly $11 \times 10^{12} \mathrm{~m}^{-1}$ compared to $8 \times 10^{12} \mathrm{~m}^{-1}$ for $M 4)$, it is less sensitive to concentration polarization phenomena and consequently to limiting flux, which just exist at pressures higher than 5 bar, for the more concentrated retentates $(\mathrm{C} 2, \mathrm{C} 3, \mathrm{C} 4)$ at low tangential flow-rates $\left(3-4 \mathrm{~m} \cdot \mathrm{s}^{-1}\right)$. 


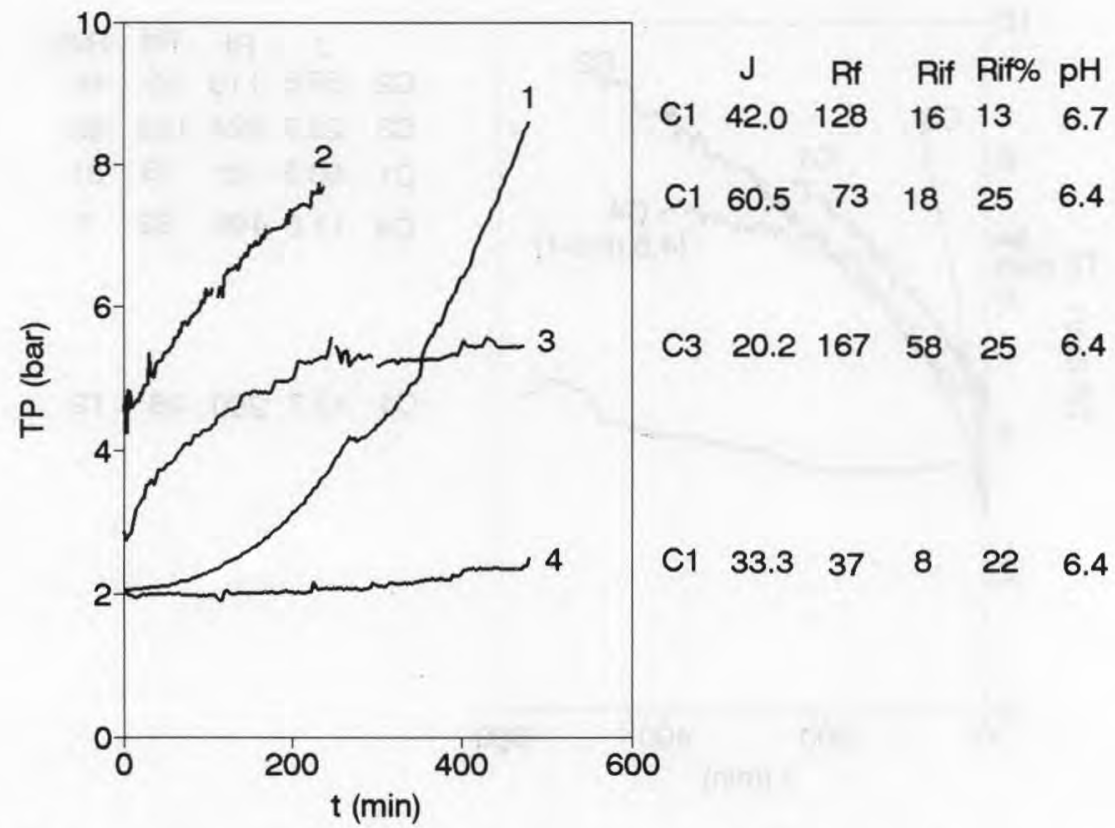

Fig 5. Fouling behaviours of M5 membrane during clarified WPC UF: transmembrane pressure (TP) versus time $(t)$ at constant flux $\left(\mathrm{J}, \mathrm{I} \cdot \mathrm{h}^{-1} \cdot \mathrm{m}^{-2}\right)\left(50^{\circ} \mathrm{C}, v=4.5 \mathrm{~m} \cdot \mathrm{s}^{-1}\right)$.

Allures de colmatage de la membrane M5 en ultrafiltration de concentrés de protéines de lactosérum clarifié : courbes TP(t) à flux constant $\left(\mathrm{J}, \mathrm{l} \cdot \mathrm{h}^{-1} \cdot \mathrm{m}^{-2}\right)\left(50^{\circ} \mathrm{C}, \mathrm{v}=4,5 \mathrm{~m} \cdot \mathrm{s}^{-1}\right)$.

The limiting flux was derived from $J$ (TP) in every UF run carried out at 4.5 $\mathrm{m} . \mathrm{s}^{-1}$. A linear relationship was found between Jlim and the logarithm of nitrogen matter concentration difference of the retentate and the permeate (regression coefficient > 0.99) for C2, C3 and C4.

In equation 2, $\mathrm{Cr}-\mathrm{Cp}$ is expressed as nitrogen matter which clearly represented the concentration of rejected protein. It should be noted that $C p$ was small as compared to $\mathrm{Cr}$ owing to high retention rate for $\beta$-lactoglobulin $(100 \%)$ and $\alpha$ lactalbumin (>95\%).

The results for $\mathrm{C} 1$ retentate from the $1 \mathrm{st}$ stage, which was not diafiltered, did not fit the model. It was therefore suggested that lactose and inorganic salts of the aqueous phase influenced the mass transfer (of proteins) within the reversible layers.

Indeed, lactose increased the fouling resistance, $R f$, by 10 to $20 \%$ (Taddéi, 1986). These results confirmed those of Kiviniemi (1977). The only effect of permeate viscosity $(+8 \%)$ does not totally explain the observed differences. Fane et al (1983) also noted an improved permeability in UF of bovine serum albumin (BSA) solutions when no salts were present at $\mathrm{pH}$ higher than 6.0-6.5. This effect was imputed to a decrease of adsorbed protein and to an increase of the BSA molecule size and charge. Banzi (1986), however, came to the conclusion that inorganic salts (cal- 


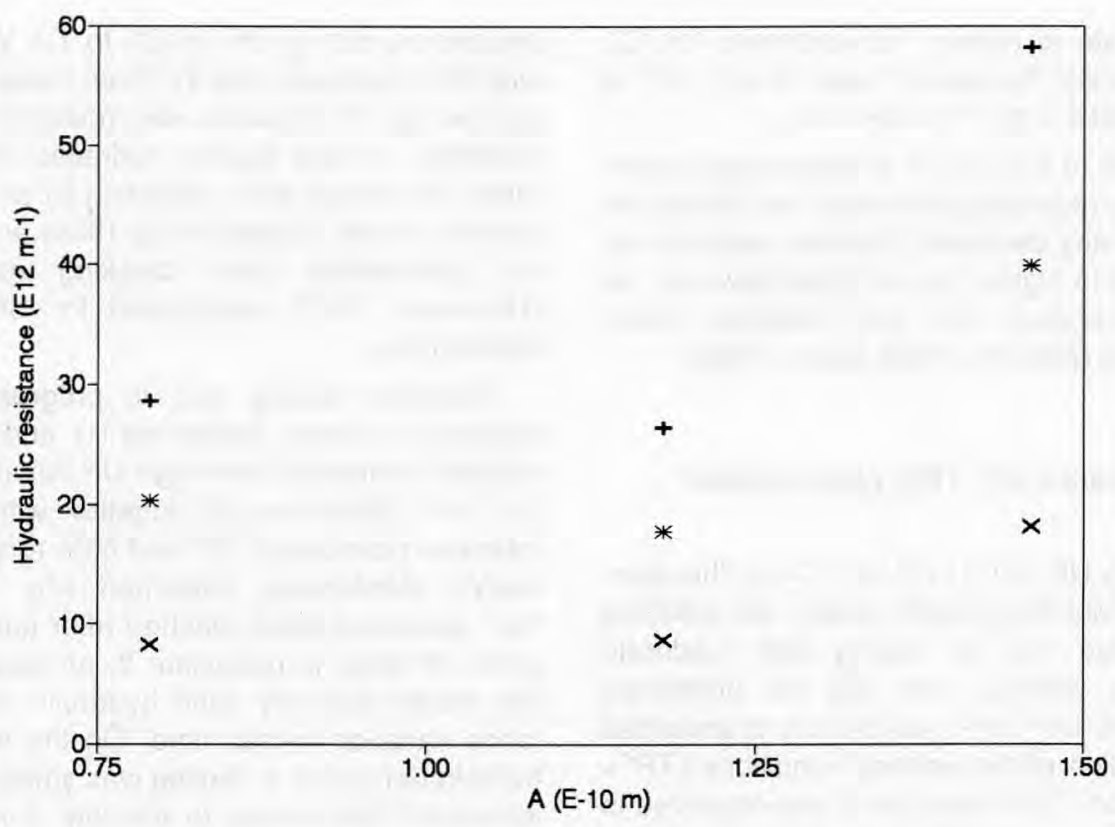

Fig 6. Hydraulic resistances (+ Rf, ${ }^{*}$ Rif, $\mathrm{x} R r f$ ) versus $A=\mu r \mathrm{~J} / \tau w$ in UF of $\mathrm{C} 1$.

Évolution des résistances hydrauliques (+ Rf, ${ }^{*} \mathrm{Rif}, x \mathrm{Rrf}$ ) en fonction de $\mathrm{A}=\mu \mathrm{r} \mathrm{J} / \mathrm{tw}$ en UF de concentrés $C 1$.

cium, phosphate, etc) played their own role.

The mass transfer coefficient, $k$, in UF of protein concentrates submitted to diafiltration (C2, C3, C4), computed from $J=$ In $(\mathrm{Cr}-\mathrm{Cp})+$ constant was $70 \mathrm{I} \cdot \mathrm{h}^{-1} \cdot \mathrm{m}^{-2}$ at 4.5 $\mathrm{m} . \mathrm{s}^{-1}$. With tangential flow rate increasing in the range 4.5 to $8 \mathrm{~m} . \mathrm{s}^{-1}, k$ values calculated according to René and Lalande's relationship (1989) varied from $68 \mathrm{l} . \mathrm{h}^{-1} \cdot \mathrm{m}^{-2}$ (C2) or 62 I. $\mathrm{h}^{-1} \cdot \mathrm{m}^{-2}$ (C4). Consequently, the higher the tangential flow rate during diafiltration or UF of previously diafiltered retentate, the higher the membrane permeability. However, operating conditions for diafiltration should be considered as a compromise between retentate purity and cost (water volume, permeation flux, extra membrane area, etc) (Goudédranche et al, 1980). Significant influence of tangential flow rate on flux was reported for sweet whey UF (Taddéi et al, 1988) or milk UF (Peri and Setti, 1976). Extrapolation of linear drawings of $J$ (C) to $J=0$ gave wall concentration in the

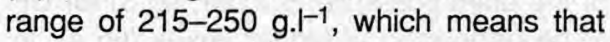
processing such high concentration would result in no permeation.

With the clarified WPC, the beneficial effect of high flow rate was principally observed at higher pressure, which seems to be connected with the influence of tangential stress, $\tau w$, on protein layers which tend to accumulate on the membrane. In fact, using Barnier's model (1990), we show that critical UF flux, over which there is a cake built up, is higher when tangential 
flow-rate is higher. For example, for C3, the critical flux was 47 and $761 . \mathrm{h}^{-1} \cdot \mathrm{m}^{-2}$ at 4.5 and $6.0 \mathrm{~m} . \mathrm{s}^{-1}$ respectively.

Due to the use of an appropriate membrane, regarding selectivity, we did not observe any decrease in protein rejection releated to higher flux at higher flow rate, as was reported for less selective membranes (Zidoune, 1983; Banzi, 1986).

\section{Constant J UF: TP(t) characteristic}

During UF of $\mathrm{C} 1, \mathrm{C} 2$ and $\mathrm{C} 4$ at the average plant flux of each stage, Jpl, pressure increase due to fouling was moderate (fig 3), whereas with $\mathrm{C} 3$ the performed flux, $20 \mathrm{I} \cdot \mathrm{h}^{-1} \cdot \mathrm{m}^{-2}$, led to more pronounced alteration of the working conditions (TPf $=$ 5.5 bar). The same trend was observed in the 3rd stage of the industrial plant (table II).

Reversible phenomena were still dominant and contributed more to the final pressure: for instance $83 \%$ for $\mathrm{C} 4$; but irreversible phenomena were not negligible, particularly for C1, C2, C3 $(30-40 \%)$. Moreover, variation of the latter (Rif) versus time was certainly responsible for permeability drift, and thus for transmembrane pressure increase. However, it left enough margin (up to the maximum value of the plant pressure, $6.3 \mathrm{bar}$; fig 3) for UF to be performed at higher fluxes (fig 4). In this case, TP is higher and its variations are faster with significant increase of Rif, particularly for $\mathrm{C} 3$, but also of reversible phenomena, whose contribution to TP increase remains in the same order of magnitude. Taking 6.3 bar as a maximum pressure value in the industrial plant, higher fluxes at which we ran UF were too high for the plant except for $\mathrm{C} 4$.

The entire experiment, carried out over a large range of fluxes, showed 4 fouling behaviours during UF of $\mathrm{C} 1$ to $\mathrm{C} 4$ WPC with M5 membrane (fig 5). From these experimental TP ( $t$ ) curves we modelled the evolution of total fouling hydraulic resistance, Rf versus time according to an adsorption model (Taddéi et al, 1989) and to an intermediate pore blocking model (Hlavacek, 1990) established for UF at constant flux.

Divergent fouling, due to progressive blocking of pores (behaviour 1) and adsorption connected with high UF flux $(60.5$ I. $\mathrm{h}^{-1} \cdot \mathrm{m}^{-2}$ ) (behaviour 2), together with an intensive polarization ( 87 and $69 \%$ respectively), satisfactorily explained why very high pressures were reached after quite a short UF time. In behaviour 3 , an adsorption model correctly fitted hydraulic resistance variation versus time. On the other hand in behaviour 4, fouling was small and increased little, owing to the low $J$ value $\left(33.6 \mathrm{I} \cdot \mathrm{h}^{-1} \cdot \mathrm{m}^{-2}\right)$ so that no model fitted the experimental data.

These fouling behaviours are similar to those found during constant pressure UF (Taddéi et al, 1989), where Rf variations were alike. Adsorption and polarization phenomena are mainly related to proteins, whereas deposits or cake are connected with insoluble salts such as phosphates (Labbé et al, 1990; Daufin et al, 1991b). This is particularly true for $\mathrm{C} 1$, which did not undergo a diafiltration step and its higher $\mathrm{pH}(6.7$ instead of 6.4$)$ led to a faster pressure increase.

Modelling the laboratory experimental results indicated some of the major actions required for limiting fouling and improving UF performance. Diminishing inorganic salt precipitation and decreasing protein ability to polarize the membrane and to adsorb to it by an appropriate whey microfiltration pretreatment have recently proven to be efficient (Daufin et al, 1990, 1991c). On the other hand, according to Barnier's convection-erosion model, the transforma- 
tion of J(TP) curves for C1, C2 and C3 in A (In Rf) did reveal a curve divided into 2 linear parts. From the break-point appeared a critical value $A c\left(1.9 \times 10^{-10} \mathrm{~m}\right.$ for $\left.\mathrm{C} 1\right)$ which corresponded to a critical flux $J c$ (68 I. $\mathrm{h}^{-1} \cdot \mathrm{m}^{-2}$ for $\mathrm{C} 1$ ). Furthermore, membrane fouling expressed as Rf, Rrf and Rif, calculated at the end of the UF run, depended on the parameter $A=\mu r . J / \tau w$ proposed by Barnier (1990). A range of $A$ values $<1.25 \times 10^{-10} \mathrm{~m}$ existed, where fouling did not increase with increase in $A$ (fig 6 ). A more detailed study on influencing $A$ by varying $\mu r, J$ and $\tau_{\mathrm{w}}$ would allow critical $A$, $A c$ relative to a combination membrane/ homogeneous range of WPC to be assessed. Then, predicting how to run UF at each stage would rely on an adequate choice of operating parameters such as $\mu r$ (protein concentration), $\tau W$ (tangential shear stress) and $J$, so that they comply with the condition:

$$
\mu r . J / \tau w<A C .
$$

Nevertheless, other operating parameters will have to be well mastered in order to avoid fast and unexpected transmembrane pressure increase under the influence of unpredictable events, for example, slightly fouled membranes after inefficient cleaning.

\section{CONCLUSION}

A knowledge of the working conditions and performance of an industrial UF plant for producing defatted WPC allowed us to perform constant flux UF (in a laboratory unit equipped with a M5 Carbosep monotube) at stationary concentration, simulating each of the 4 UF stages.

For the M5 membrane, whey clarification does not change protein rejection (it remains at nearly $100 \%$ ) but enhances membrane permeability. No well-marked limiting fluxes were observed, particularly at sufficiently high flow rates (4.5 or 5.5 $\mathrm{m} . \mathrm{s}^{-1}$ ), which enabled performance of UF at higher fluxes to be proposed.

Defatted WPC UF under some flux conditions (equal and higher than the industrial plant flux encountered in each stage) showed 4 fouling behaviours which are strongly dependent on $J$ value, protein concentrations, tangential flow rate and nature of the fouling components (proteins which adsorb and insoluble inorganic particulates which accumulate onto and within the membrane pores). Reversible phenomena are dominant, but irreversible fouling, Rif, and its increase rate determine either quasi-stability of UF conditions or their divergence, which corresponds to an increasingly rapid transmembrane pressure.

Thus, the strategy for optimizing UF consists of lowering fouling; this is not only irreversible, by benefitting from results of an analytical study of foulants, but also reversible, by better mastering mass transfer conditions, tangentially to the membrane or through it.

\section{ACKNOWLEDGMENTS}

This work was partially supported by grant from the Direction Générale de I'Alimentation (R89/ 10) of the French Ministry of Agriculture. We thank JJ Maugas and JP Dupont (Société Eurial, Nantes, France) for helpful discussion about the 4-stage industrial UF plant.

\section{REFERENCES}

Barnier $\mathrm{H}$ (1990) Fouling problems in membrane filtration. 5th World Filtration Congr, Nice, 1 , 548-552

Banzi A (1986) Concentration du lactosérum par ultrafiltration. Thesis, Toulouse 
Brulé G, Maubois JL, Fauquant J (1974) Étude de la teneur en éléments minéraux des produits obtenus lors de l'ultrafiltration de lait sur membrane. Lait 54, 600-615

Daufin G, Michel F, Merin U (1990) Ultrafiltration of defatted whey: influence of some physicochemical characteristics. Aust J Dairy Technol (submitted)

Daufin G, Merin U, Labbé JP, Quemerais A, Kerhervé FL (1991a) Cleaning of inorganic membranes after whey and milk ultrafiltration. Biotechnol Bioeng 38, 82-89

Daufin G, Labbé JP, Quemerais A, Michel F (1991b) Fouling of an inorganic membrane during ultrafiltration of defatted whey protein concentrate. Neth Milk Dairy J 45, 259-272

Daufin G, Michel F, Labbé JP, Quemerais A, Radenac JF, Kerhervé FL (1991c) Ultrafiltration of defatted whey, improving performances. 4th World Congr Chem Eng, Karlsruhe, June 16-21

Delaney RAM, Donnelly JK (1977) Reverse Osmosis and Synthetic Membranes. Theory, Technology, Engineering (Sourirajan S, ed) Nat Res Council, Ottawa, Canada

Fane AG, Fell CJD, Suki A (1983) The effect of $\mathrm{pH}$ and ionic environment on the ultrafiltration of protein solutions with retentive membranes. J Membrane Sci 16, 195-210

Fauquant J, Vieco $\mathrm{S}$, Brulë $\mathrm{G}$, Maubois $\mathrm{JL}$ (1985) Clarification des lactosérum doux par agrégation thermocalcique de la matière grasse résiduelle. Lait $65,1-20$

Gekas V, Hallstrom B (1987) Mass transfer in the membrane concentration polarization layer under turbulent cross flow. I. Critical literature review and adaptation of existing Sherwood correlations to membrane operations. J Membrane Sci 30, 153-170

Goudédranche $H$, Maubois $J L$, Ducruet $P$, Mahaut M (1980) Utilization of the new mineral UF membranes for making semi-hard cheeses. Desalination 35, 243-258

Hlavacek M (1990) Contribution à l'étude de la filtration des colloïdes sur membrane, avec une attention particulière pour la charge électrique des particules. Thesis, Institut National Polytechnique, Nancy

Kiveniemi L (1977) Processing of Sweet Whey and Skim Milk by Ultrafiltration. Valio Lab Publ Helsinki, Finland
Labbé JP, Quemerais A, Michel F, Daufin G (1990) Fouling of inorganic membranes during whey ultrafiltration: analytical methodology. J Membrane Sci 51, 293-307

Marshall KR, Harper WJ (1988) Whey protein concentrates. Int Dairy Fed Bull 233, 21-32

Maubois JL (1987) Recent developments in the application of membrane technology. Conf Agricultural College Ayr, Scotland, UK

Maubois JL (1988) Whey, its biotechnological signification. In: Proc 8th Int Biotechnol Symp (Durand G, Bobichon L, Florent J, eds) Soc Fr Microbiol Paris, 2, 814-824

Maubois JL, Pierre A, Fauquant J, Piot M (1987) Industrial fractionation of main whey proteins. Trends in whey utilization. Int Dairy Fed Bull 212, 154-159

Merin V, Gordin S, Tanny GB (1983) Microfiltration of sweet cheese whey. NZJ Dairy Sci Technol 18, 154-160

Michaels AS (1968) New separation technique for the CPI. Chem Eng Prog 64, 31

Muller LL, Harper WJ (1979) Effects on membrane processing of pretreatments of whey. $J$ Agric Food Chem 27, 662-664

Patocka J, Jelen P (1987) Calcium chelation and other pretreatments for flux improvement in ultrafiltration of cottage cheese whey. J Food Sci 52, 1241-1244

Peri C, Setti D (1976) Whey and skimmilk ultrafiltration. 1. Parameters affecting permeation rate in sweet whey ultrafiltration. Milchwissenschaft 31, 135-138

Piot M, Maubois JL, Schaegis P, Veyre R, Luccioni $A$ (1984) Microfiltration en flux tangentiel des lactosérum de fromagerie. Lait 64, 102-120

René F, Lalande M (1989) Design of a new correlation for polarization layer linked mass transfer during ultrafiltration of dextran in high turbulent flow regimes. 5th Int Congr Eng Food, Cologne, May 28-June 3, poster 54.03

Taddéi C (1986) Mécanismes influençant le transfert de matière lors de l'ultrafiltration de lactosérum. Thesis, Toulouse

Taddéi C, Aimar P, Daufin G, Sanchez V (1986) Étude du transfert de matière lors de I'ultrafiltration de lactosérum doux sur membrane minérale. Lait 66, 371-390

Taddéi C, Aimar P, Daufin G, Sanchez V (1988) Factors affecting fouling of an inorganic 
membrane during sweet whey ultrafiltration. Lait 68, 157-176

Taddéi C, Daufin G, Aimar P, Sanchez V (1989) Role of some whey components on the mass transfer in ultrafiltration. Biotechnol Bioeng 34, 171-179

Tarnawski VR, Jelen P (1986) Estimation of compaction and fouling effects during membrane processing of cottage cheese whey. $J$ Food Eng 5, 75-90
Van den Berg GB, Smolders CA (1990) Flux decline in membrane processes. Desalination 77, 101-133

Van der Horst HC, Hanemaaijer JH (1989) Cross-flow microfiltration in food industry: state of the art. Membrane Technol Symp, Tylosand, Sweden, June 12-14

Zidoune MN (1983) Étude de l'ultrafiltration des lactosérum sur membranes minérales. Thesis, Montpellier 